\title{
Food-away-from-home expenditure in Mexico during the COVID-19 pandemic: A micro-econometric analysis
}

\author{
Antonio Aguilar-Lopez ${ }^{1}$ and Aleš Kuhar ${ }^{2, *}$ \\ 1 División de Ingeniería en Gestión Empresarial, Instituto Tecnológico Superior de Huichapan, Tecnológico \\ Nacional de México, Domicilio Conocido S/N Colonia El Saucillo, 42411 Huichapan, México; aagui- \\ lar@iteshu.edu.mx \\ 2 Biotechnical Faculty, University of Ljubljana, Jamnikarjeva ulica 101, 1000 Ljubljana, Slovenia; \\ ales.kuhar@bf.uni-lj.si \\ * Correspondence: ales.kuhar@bf.uni-lj.si
}

\begin{abstract}
The propagation of the coronavirus disease 2019 (COVID-19) reshaped the relationship between income and food-away-from-home (FAFH) expenditure in Mexico during 2020. Although the number of households participating in this market fell across income deciles and regions due to the pandemic, the impact on their budget shares is not uniform. Using data from the Encuesta Nacional de Ingresos y Gastos de los Hogares (ENIGH) 2020, we estimated an Engel curve of the Working-Lesser functional form for FAFH. Among the independent variables are the number of family members 65 years of age and older, and dummies to indicate whether the household experienced food insecurity or received remittances. The estimation was carried out following the Heckman two-step method, suitable for censored-response data. The results suggest that the budget share for FAFH drops as income increases. The number of older adults and food insecurity discourage the decision to participate in FAFH expenditure and increase its budget share, whereas remittances encourage participation and reduce its budget share. The corrected conditional elasticity is 0.4609; the sign and the magnitude indicate that FAFH is a necessity good.
\end{abstract}

Keywords: elasticity, Engel curve; food-away-from-home expenditure

\section{Introduction}

Since the inception of the coronavirus disease 2019 (COVID-19) pandemic, several public health interventions were implemented to reduce the transmission all over the world. In Mexico, such interventions included cancellation of mass gathering events, schools and workplace closures, and social distancing. Groups susceptible to develop severe infection were encouraged to stay at home, such as older people and those affected with chronic diseases. Some of these interventions affected the expenditure on food-awayfrom home (FAFH) directly, like the limitation of the time span that eating out facilities were open to the public, as well as the mandate to operate at a fraction of their capacity.

Taking advantage of the availability of nationwide microeconomic data on household expenditures, the Encuesta Nacional de Ingresos y Gastos de los Hogares (ENIGH), we traced the evolution of FAFH expenditure from 2008 to 2020 across income all deciles. From this examination, we found that the changes brought about by the propagation of the virus in the country, reshaped the relationship between income and FAFH expenditure during 2020. The participation of households in this type of expenditure dropped across all income deciles, reversing the slightly positive trends observed over the previous decade (Figure 1). 


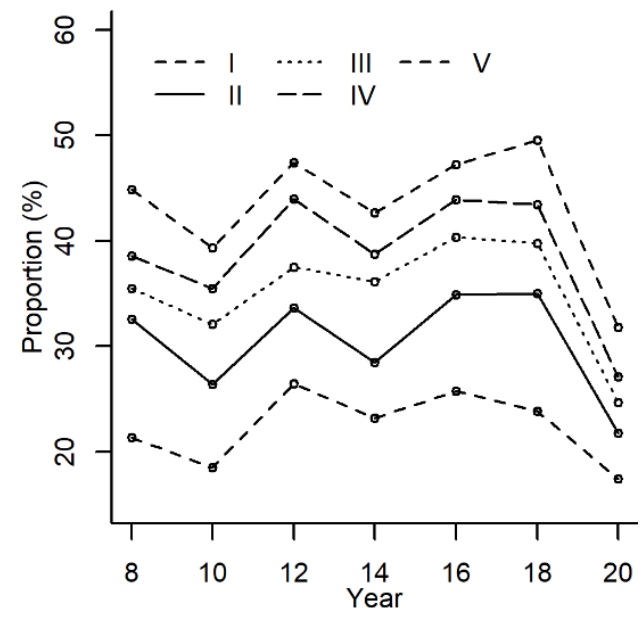

(a)

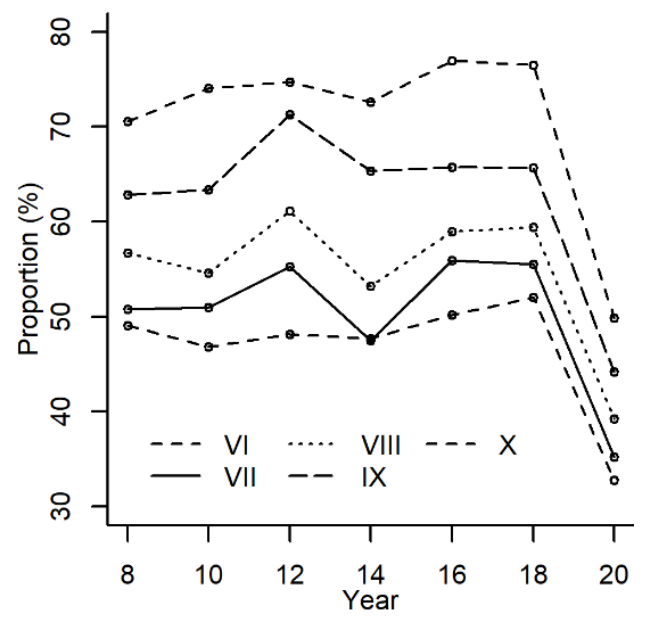

(b)

Figure 1. Proportion of households where FAFH > 0 by income decile, 2008-2020, for: a) Lower deciles; (b) Upper deciles. Quaterly data (fuera_hog or ali_fuera depending on the survey). Source: own elaboration with data from Instituto Nacional de Estadística y Geografía (INEGI) [1].

However, the effect on the budget shares for FAFH (i.e., the expenditure to income ratio) across income deciles was not uniform in 2020. Broadly speaking, they increased in the lower deciles, remained stable in the middle, and fell in the upper levels (Figure 2). Interestingly, a similar drop in the upper levels was present in 2008, during the global financial crisis, though household participation wasn't damaged.

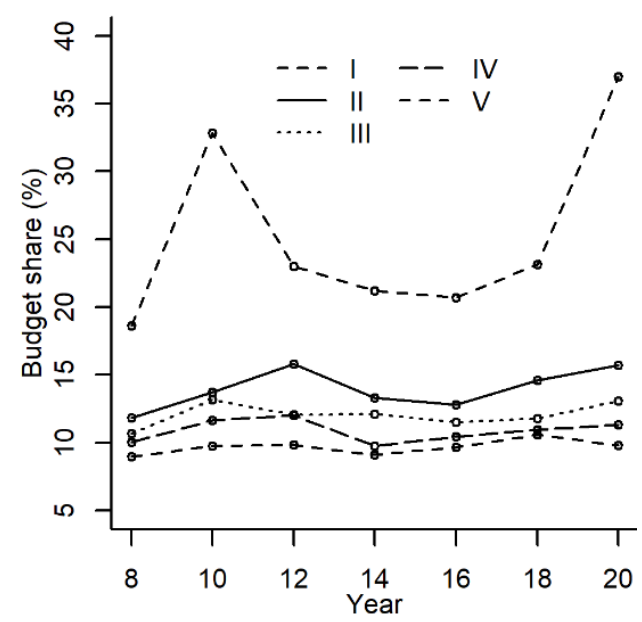

(a)

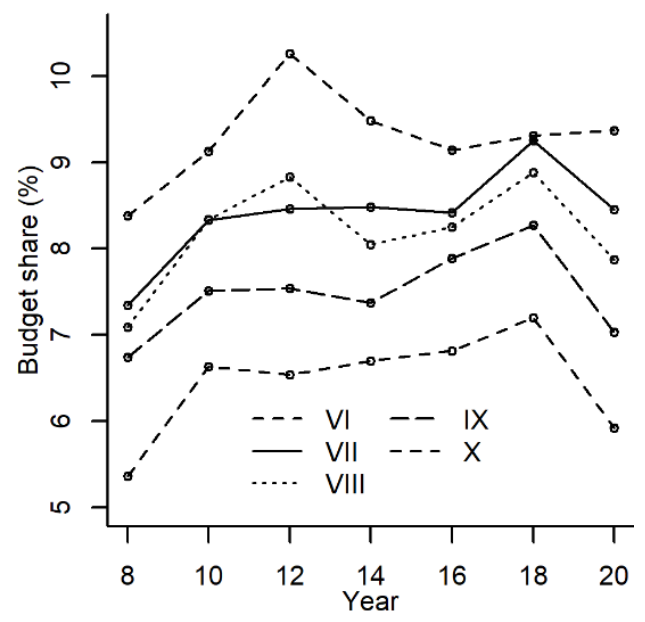

(b)

Figure 2. Average budget share for FAFH expenditures by income decile (for households where budget share > 0), 2008-2020, for: a) Lower deciles; (b) Upper deciles. Quaterly data (fuera_hog or ali_fuera depending on the survey). Budget share for households with no income was set to 0 for decile I. Source: own elaboration with data from INEGI [1].

Furthermore, the impact of the pandemic on FAFH expenditure participation was not evenly distributed in spatial terms. Using a data-intensive analysis we tracked the development of household participation on FAFH expenditure by state. For 2018, the data indicates that the states with the highest participation were Colima, Ciudad de México, and Jalisco, whereas Nuevo León, Coahuila, and Chiapas had the lowest participation. In 2020, the states that experienced the sharpest drop in household participation were Campeche, Sinaloa, and Oaxaca. The relatively less affected states were Michoacan, Nayarit, and Aguascalientes (Table 1). 
Table 1. Proportion of households where FAFH > 0 by state, ENIGH's 2008-2020. Quaterly data (fuera_hog or ali_fuera depending on the survey).

\begin{tabular}{|c|c|c|c|c|c|c|c|c|}
\hline State & 2008 & 2010 & 2012 & 2014 & 2016 & 2018 & 2020 & $\Delta(\%))^{1}$ \\
\hline Aguascalientes & 55.51 & 52.39 & 51.20 & 49.91 & 53.87 & 58.19 & 42.82 & -26.41 \\
\hline Baja California & 44.05 & 50.62 & 61.31 & 51.57 & 56.68 & 60.68 & 36.46 & -39.91 \\
\hline Baja California Sur & 55.67 & 39.05 & 51.36 & 40.56 & 43.04 & 47.65 & 30.89 & -35.17 \\
\hline Campeche & 57.25 & 43.98 & 41.32 & 39.39 & 48.33 & 50.27 & 18.32 & -63.56 \\
\hline Coahuila & 34.96 & 30.88 & 43.53 & 43.90 & 35.51 & 33.47 & 18.50 & -44.73 \\
\hline Colima & 54.71 & 54.42 & 56.09 & 56.25 & 58.45 & 65.70 & 44.18 & -32.75 \\
\hline Chiapas & 35.19 & 21.78 & 27.47 & 28.87 & 28.28 & 32.73 & 21.04 & -35.72 \\
\hline Chihuahua & 31.97 & 17.37 & 15.30 & 39.60 & 38.86 & 45.63 & 28.79 & -36.91 \\
\hline Ciudad de México & 63.64 & 59.81 & 65.82 & 58.91 & 68.11 & 64.78 & 45.43 & -29.87 \\
\hline Durango & 45.49 & 41.30 & 47.65 & 36.98 & 40.98 & 37.60 & 20.37 & -45.82 \\
\hline Guanajuato & 43.06 & 35.77 & 56.04 & 41.31 & 51.69 & 44.80 & 30.92 & -30.98 \\
\hline Guerrero & 50.76 & 56.16 & 54.91 & 55.17 & 54.22 & 48.64 & 26.15 & -46.24 \\
\hline Hidalgo & 31.98 & 34.76 & 51 & 51.89 & 44.77 & 49.93 & 28.06 & -43.80 \\
\hline Jalisco & 53.41 & 63.54 & 54 & 57.11 & 62.06 & 64.68 & 46.07 & -28.77 \\
\hline Mé & 47.24 & 39 & 77 & 39 & 47.66 & 56.68 & 41.08 & -27.52 \\
\hline Michoacán & 48.54 & 44.75 & 64.43 & 57.35 & 61.63 & 53.91 & 46.63 & -13.50 \\
\hline Morelos & 57.13 & 49.83 & 52.83 & 54.44 & 56.52 & 56.44 & 36.25 & -35.77 \\
\hline Nayarit & 59.40 & 61.06 & 59.33 & 60.08 & 57.67 & 48.86 & 39.52 & -19.12 \\
\hline Nuevo León & 41.80 & 48.78 & 41.40 & 44.52 & 44.94 & 36.58 & 23.57 & -35.57 \\
\hline Oaxaca & 30.09 & 36.88 & 43.89 & 49.45 & 41.72 & 44.40 & 23.29 & -47.55 \\
\hline Puebla & 44.70 & 41.26 & 44.17 & 45.99 & 49.37 & 44.47 & 27.80 & -37.49 \\
\hline Querétaro & 44.95 & 54.14 & 49.65 & 52.09 & 52.62 & 51.37 & 35.97 & -29.98 \\
\hline Quintana Roo & 51.08 & 58.55 & 60.08 & 46.18 & 58.23 & 59.83 & 32.13 & -46.30 \\
\hline San Luis Potosí & 42.12 & 39.39 & 51.46 & 46.74 & 44.06 & 40.33 & 26.32 & -34.74 \\
\hline Sinaloa & 47.69 & 38.23 & 30.04 & 38.08 & 48.51 & 49.20 & 24.87 & -49.45 \\
\hline Sonora & 38.84 & 53.36 & 50.58 & 45.09 & 51.48 & 48.04 & 31.52 & -34.39 \\
\hline Tabasco & 37.26 & 37.52 & 48.12 & 45.46 & 42.99 & 40.77 & 21.92 & -46.23 \\
\hline Tamaulipas & 44.02 & 34.63 & 56.68 & 36.24 & 51.50 & 43.88 & 24.44 & -44.30 \\
\hline Tlaxcala & 47.79 & 65.92 & 37.96 & 48.52 & 47.01 & 46.33 & 25.87 & -44.16 \\
\hline Veracruz & 47.87 & 27.24 & 49.29 & 41.97 & 43.43 & 43.94 & 23.16 & -47.29 \\
\hline Yucatán & 53.11 & 50.88 & 60.35 & 55.03 & 52.13 & 53.51 & 29.04 & -45.73 \\
\hline Zacatecas & 38.55 & 29.62 & 43.28 & 39.78 & 33.62 & 40.91 & 27.10 & -33.76 \\
\hline
\end{tabular}

${ }^{1}$ Change in the proportion of households where FAFH $>0$ between 2018 and 2020, by state.

Source: own elaboration with data from INEGI [1].

It is important to point out that before COVID-19, Mexico was already one the members of the Organisation for Economic Co-operation and Development (OECD) with high levels of income inequality (Gini coefficient $=0.418$ in 2018). In 2020, the share of the population experiencing some degree of poverty stood at $43.9 \%$, up from $41.9 \%$ in 2018 ; moreover, wages fell $10.3 \%$ on average for those employees who were able to keep their jobs [2], and $24.92 \%$ of the firms in the service sector shut down definitely [3].

On the other hand, Mexico was among the top five countries receiving inflows of money from abroad in 2020 . With over 40,000 million dollars (3.8\% of GDP), remittances stood as the second source of income entering the country that year. This influx, coupled with the depreciation of the currency, helped to shore up household consumption [4].

This new setting calls for an assessment of the relationship between income and FAFH expenditure under the conditions in 2020. Thus, the objective of in this paper is to estimate an Engel curve for FAFH expenditure in Mexico in 2020. Since we stick to the stringent version of Engel's Law, we use income as the main independent variable and FAFH's budget share as the dependent variable. We hypothesized and confirmed that 
FAFH drops as income increases, providing evidence in support of Engel's Law. A secondary objective is to provide an estimate for income elasticity.

In 1857 the German statistician Ernst Engel (1821-1896), published the article: "Die Produktions-und Consumtionsverhältnisse des Königreichs Sachsen", in which the relationship between household expenditure and income was systematically studied for the first time. In the article, expenditure categories were classified according to the wants they served, following Adam Smith's notion that the extent to which individuals can satisfy their own wants is the definitive measure of welfare; thus, the welfare implications of Engel's results may be interpreted in this fashion. The main of such categories, measured as a proportion of income, was nourishment, which encompassed daily nourishment from meals and beverages, as well as spices, alcohol, coffee, tobacco, occasional dining out, and other expenditures. The lasting result from the article, known as Engel's Law, is the principle stating that low-income households spend a larger proportion of their budget on nourishment [5].

One of the ways that Engel's work differed from previous literature is the categorization of goods in line with the wants they ultimately satisfy, rather than analyzing them individually. A second distinction is the rejection to classify goods into necessary and luxury goods; the former being intrinsically more advantageous for human welfare than the latter [5]. Afterwards, the focus of the research into expenditure patterns shifted again towards the individual analysis of goods and services.

When considering the case of food, even if Engel's Law should hold in the aggregate, the same cannot be assumed for the components that make up the category, to which such principle is originally related [6]. This fact gave rise to a series of studies separating food expenditure into sub-categories.

Some studies split up the expenditure on nourishment into two branches: food-athome (FAH) and food-away-from-home (FAFH). The foundations for the distinction can be derived from Becker's Theory of the Allocation of Time, which extended the classical demand theory to consider the effect of prices, income, demographics, opportunity costs, and time restrictions on household expenditures. Under this approach, the cost of food can be augmented to include the time assigned to all the phases involved in the act of eating. The resources of the household are constrained; therefore, it decides, depending on its attributes, whether to allocate time to all the phases (i.e., prepare FAH) or to subcontract some of them (i.e., eat FAFH) [7].

In the United States, the second half of the 20th century witnessed how FAFH expenditures grew at a faster rate than FAH expenditures, with the consequence that the former rose as a proportion of total food (TF) expenditure. This trend prompted domestic research [8-13], which later spread to countries like Bangladesh [14], China [15], Slovakia [16], Spain [17] and Turkey [18]. Some refinements to the FAFH category are the inclusion of the type of food facility [19] and consumption circumstance [20]. These trends are relevant for the functioning of agricultural markets and resource allocation.

One strand of the literature on FAFH expenditure was devoted to gauge whether Engel's Law extends to this subcategory $[6,21]$ using the so-called Engel curves. In microeconomics, Engel curves are used to describe household expenditure on goods or services as a function of household income.

Household surveys have been used in several countries to estimate Engel curves for FAFH. Lanfranco, Ames, and Huang [22] analyzed food expenditure patterns for Hispanic households in the United States estimating curves for three food categories: TF, FAH and FAFH; the data was compiled using the 1994-1996 Continuing Survey of Food Intakes by Individuals. Tey, Shamsudin, Mohamed, Abdullah, \& Radam [23], found evidence of the curves for FAFH in Malaysia, using the Household Expenditure Survey 2004/2005. García Arancibia [20], estimated curves for total FAFH and two consumption circumstances in Argentina, using data from the Encuesta Nacional de Gastos de Hogares 19961997. More recently, Queiroz \& Coelho [24], used the Pesquisa de Orçamentos Familiares 2008-2009 to fit curves for Brazil. 
Studies on FAFH expenditure in Mexico include the use of a binomial logit to analyze the determinants of the probability for households to participate in this market, using data from 1992 and 2008 [25]; and an analysis of the changes in its budget share and frequency in the period 1984-2014 [26]. Both instances have in common the use of the data provided by the national survey Encuesta Nacional de Ingresos y Gastos de los Hogares (ENIGH). There is, nevertheless, no current research aimed at studying whether Engel's Law extends to FAFH expenditures in Mexico; moreover, these studies were conducted in a period of relative economic stability.

We use a two-step estimation method made up of one participation equation and a level equation for the households. We further hypothesize that income and receiving remittances increase the probability of participation, whereas the number of family members 65 of age and older and food insecurity reduce the probability of participation.

Studies carried out over the years indicate that FAFH expenditure can be classified as necessary rather than luxury good in countries like the Argentina, Malaysia, and the United States [10, 12, 13, 19-23]. However, these results cannot be generalized, since in places like Slovakia, FAFH is perceived as a luxury good [16].

The rest of the paper is organized as follows. In Section Materials and Methods, we describe the Heckman two-step procedure to estimate single equation representations of Engel Curves, then the variables used in the procedure, and the data base. The Results section presents the estimates of the Heckman model. Finally, in the Discussion section, we interpret the meaning of the results considering similar studies.

\section{Materials and Methods}

The Encuesta Nacional de Ingresos y Gastos de los Hogares (ENIGH) is a comprehensive statistical outlook which tracks the behavior of income and expenditures of households in Mexico. It is common to find zero-expenditure records for some goods or services in the survey, a phenomenon known as the censored-data. The Heckman (or Heckit) two-step procedure has been used to circumvent this problem in single equation representations of Engel curves [27].

The Heckman procedure builds upon the idea that censored data on household expenditure on goods and services can be understood as a combination of a selection mechanism for the decision to purchase and a model for the level of consumption or expenditure.

The selection mechanism, the first step, is represented by the decision equation:

$$
d_{i}=\boldsymbol{z}_{i}^{\prime} \boldsymbol{\gamma}+u_{i}
$$

This step is applied to the full sample of households. In the representation, $d_{i}$ is an indicator variable that takes the value of 1 if expenditure is observed in household $i$ and 0 otherwise; vector $\boldsymbol{z}_{i}$ represents the regressors that affect the decision to purchase and include a set of observed socio-demographic characteristics of the household; and $\gamma$ is a vector of coefficients determined by the Maximum Likelihood (ML) estimation of a Probit model where:

$$
\operatorname{Pr}\left[d_{i}=1 \mid \mathbf{z}_{i}\right]=\Phi\left(\mathbf{z}_{i}^{\prime} \boldsymbol{\gamma}\right)
$$

The purpose of the first step it to generate estimates for the bias correction term (also known as the inverse Mills ratio, or IMR) given by:

$$
\hat{\lambda}_{i}=\phi\left(\mathbf{z}_{i}^{\prime} \widehat{\gamma}\right) / \Phi\left(\mathbf{z}_{i}^{\prime} \widehat{\gamma}\right)
$$

where $\Phi$ is the standard normal cumulative distribution function and $\phi$ is the standard normal probability density function.

In the second step, Ordinary Least Squares (OLS) or Generalized Least Squares (GLS) are applied to the chosen functional form of the Engel curve plus the IMR. GLS are the favored method in the presence of heteroskedasticity, which is a common trait in crosssectional data. Thus, the level equation is: 


$$
y_{i}=\boldsymbol{x}_{i}^{\prime} \boldsymbol{\beta}+\theta \hat{\lambda}_{i}+\varepsilon_{i}
$$

where $\boldsymbol{x}_{i}$ represents a vector of socio-demographic features of the household that affect the level of expenditure. This step uses only the sample of households where expenditure is observed.

In the paper at hand, the decision equation is given by:

$$
d_{i}=\gamma_{1}+\gamma_{2} \ln \left(\text { income }_{i}\right)+\sum_{k=3}^{k} \gamma_{k} z_{k, i}+u_{i}
$$

where $d_{i}$ indicates whether FAFH expenditure is observed in household $i$.

The Engel curve used in the second step follows the Working-Lesser form, because it allows a direct test of Engel's Law [21]. Thus, the level equation is:

$$
y_{i}=\beta_{1}+\beta_{2} \ln \left(\text { income }_{i}\right)+\sum_{k=3}^{k} \beta_{k} x_{k, i}+\theta \hat{\lambda}_{i}+\varepsilon_{i},
$$

where $y_{i}$ stands for the budget share of food-away-from-home (FAFH) expenditures. This equation indicates that the share of income devoted to FAFH, its budget share, tends to change in arithmetic progression as income changes in geometric progression.

In this paper we present a corrected estimate for the income elasticity of the budget share of FAFH (i.e., monetary spending on goods and services for the household). At the mean of the data, the elasticity is given by:

$$
e_{s}=1+\frac{1}{E\left(y_{i}\right)}\left[\hat{\beta}_{2}+\hat{\theta} E\left(\frac{\partial}{\partial z_{2}} \hat{\lambda}_{i}\right)\right]
$$

where $z_{2}=\ln ($ income $)$. This is equivalent to [27]:

$$
e_{s}=1+\frac{1}{E\left(y_{i}\right)}\left[\hat{\beta}_{2}-\hat{\theta} \hat{\gamma}_{2}\left\{E\left(\mathbf{z}_{i}^{\prime} \hat{\gamma}\right) E\left(\hat{\lambda}_{i}\right)+E\left(\hat{\lambda}_{i}{ }^{2}\right)\right\}\right]
$$

The data used in this paper was gathered by Mexico's Instituto Nacional de Estadística y Geografía (INEGI) and are representative at the national level. The survey comes with a set of tables covering the amount, source and distribution of income, the demographic characteristics of the members of the household, and the physical features of the living space. The main attributes of every household in the sample are found in the table 'concentradohogar', which contains records for expenditure on selected food groups (including FAFH) and income.

The FAFH category of expenditure defined by the ENIGH adds up three kinds of expenditure:1) G1 or monetary on goods and services for the household, 2) G6 or nonmonetary due to transfers from institutions, and 3) G4 or non-monetary due to payments in kind. In this analysis, we take G1 as the measure of FAFH expenditure.

The dependent variables used in the analysis are: fafh_dum is a dummy variable equal to 1 if quarterly expenditure on food and beverages away from home is observed (i.e., G1 $>0$ ), and 0 otherwise; and fafh_bsh is the ratio of quarterly expenditure on food and beverages away from home to quarterly current income (G1/income).

The independent variables are: income, equal to the household's quarterly current income (sum of income from jobs, rents, transfers, imputed rent, etc); household size, equal to the number of household members (domestic workers and their families are not included, nor guests); age measures the household manager's age; woman is a dummy variable for the biological sex of the head of the household equal to 0 if man; employed, equal to the number of household members employed (14 years of age and older); hours is the sum of the hours worked by members of the household 14 years of age and older over the previous week; $p 11$ is equal to the number of household members with 11 years of age and younger; $p 65$ is equal to the number of household members with 65 years of age and older; food insecurity is a dummy variable indicating whether the household feared running out of food in the previous quarter due to lack of income or resources, equal to 1 if affirmative, 0 otherwise; urban, a dummy variable equal to 1 for households in locations with 15,000 inhabitants or more, and 0 otherwise; internet, automobile, microwave are categorical variables indicating whether the corresponding item is present in the household, equal to 1 if 
affirmative, 0 otherwise; and tourism indicates whether the household shows expenditure on tourism parties, lodging and accommodation, equal to 1 if affirmative and 0 otherwise.

Following the notion that scholarships are a source of income that may increase the probability of FAFH expenditure for households in Mexico [25], we added the variable scholarship which indicates whether the household received income of this kind from government or other institutions, equal to 1 if affirmative, 0 otherwise. In the same fashion, we added the dummy variable remittances to indicate whether the household receives income from abroad (usually family members living in the United States), equal to 1 if affirmative, 0 otherwise.

The categorical variable region has the following levels: NW (Baja California, Baja California Sur, Chihuahua, Durango, Sinaloa, and Sonora), NE (Coahuila, Nuevo León, and Tamaulipas), W (Colima, Jalisco, Michoacán, and Nayarit), E (Hidalgo, Puebla, Tlaxcala, and Veracruz), CN (Aguascalientes, Guanajuato, Querétaro, San Luis Potosí, and Zacatecas), CS (Ciudad de México, Estado de México, and Morelos), SW (base; Chiapas, Guerrero, and Oaxaca), and SE (Campeche, Quintana Roo, Tabasco, and Yucatán). The levels for the variable education of the head of the household are: None or Kindergarten (base), Primary, Secondary, Highschool, and Professional and graduate (incomplete or complete in every instance). The levels for the variable household type are: Unipersonal, Nuclear (base), Extended, Composite, and Co-resident.

The ENIGH 2020 contains 89,006 records. However, for the budget shares to be confined between zero and one, households that reported no income or expenditure either on FAFH or FAH greater than income were removed from the sample. This rendered a subset of 87,274 households.

The data indicate that, on average, households devoted approximately $2.71 \%$ of their income to FAFH (as measured by G1). Moreover, $28.22 \%$ of the households in the sample participated in FAFH consumption during 2020. (The survey was conducted between 21 August and 28 November). The summary statistics for the main variables used in the analysis are showed in Table 2.

Table 2. Descriptive statistics of the variables used in the analysis.

\begin{tabular}{cccccc}
\hline Variable & Non-zeros (\%) & Mean $^{1}$ & Std. Dev. & Min & Max \\
\hline Income & 100.00 & $48,589.24$ & $71,771.77$ & $1,096.72$ & $10,702,107.40$ \\
FAFH (G1+G6+G4) & 29.27 & $1,262.86$ & $3,515.84$ & 0.00 & $157,371.39$ \\
G1 & 28.22 & $1,237.98$ & $3,504.97$ & 0.00 & $157,371.39$ \\
G6 & 0.08 & 0.86 & 46.42 & 0.00 & $6,428.50$ \\
G4 & 1.43 & 24.02 & 274.75 & 0.00 & $26,999.91$ \\
\hline
\end{tabular}

${ }^{1}$ Figures in Mexican pesos. Source: own elaboration with data from INEGI [1].

The data analysis was carried out using the open-source software $\mathrm{R}$, version 4.1.1, and RStudio Desktop 2021.09.0+351. In the first step, we fitted the participation equation considering the ENIGH's sampling design, using the soyglm function from the survey package, version 4.1-1. In the second step, the fit considered frequency weights recovered from the sampling design and used the $l m$ function from the stats package, version 4.1.1. The code is available upon request.

\section{Results}

Table 3 shows the results for the Heckit two-step estimation of the Engel curve for food-away-from-home (FAFH) expenditure in Mexico, using the data from the Encuesta Nacional de Ingresos y Gastos de los Hogares (ENIGH) 2020. The first column presents the results of the Maximum Likelihood (ML) estimation of the Probit (survey wheighted) model used in the first step, whereas the second presents the results of the Ordinary Least Squares (OLS) estimation of the second step (weighted by the variable factor available in the data set). 
Table 3. Heckit estimates of the Engel curve for FAFH expenditure.

\begin{tabular}{|c|c|c|}
\hline \multirow[b]{2}{*}{ Covariate $^{1}$} & \multicolumn{2}{|c|}{ Dependent variable } \\
\hline & Fafh_dum (Probit) & Fafh_bsh (OLS) \\
\hline Ln (income) & $0.3354^{* * *}(0.0140)$ & $-0.0616^{* * *}(0.0023)$ \\
\hline Household size & $-0.1408^{* * *}(0.0091)$ & \\
\hline Age & $-0.0105^{* * *}(0.0006)$ & $-0.0002(0.0001)$ \\
\hline Employed & $0.0962^{* * *}(0.0114)$ & $0.0005(0.0012)$ \\
\hline Hours & $0.0015^{* * *}(0.0002)$ & $0.0001^{* *}(0.00002)$ \\
\hline P11 & $0.0238^{*}(0.0122)$ & $-0.0021^{*}(0.0011)$ \\
\hline P65 & $-0.0389^{* *}(0.0154)$ & $-0.0006(0.0019)$ \\
\hline Food insecurity & $-0.0740^{* * *}(0.0150)$ & $-0.0094^{* * *}(0.0020)$ \\
\hline Internet & $-0.0090(0.0173)$ & $0.0023(0.0022)$ \\
\hline Automobile & $0.1004^{* * *}(0.0176)$ & $0.0080^{* * *}(0.0020)$ \\
\hline Microwave & $0.0905^{* * * *}(0.0159)$ & $0.0066^{* * *}(0.0020)$ \\
\hline Tourism & $0.2166^{* * *}(0.0372)$ & $0.0025(0.0040)$ \\
\hline $\mathrm{CN}$ & $0.0232(0.0278)$ & \\
\hline NW & $-0.1792^{* * *}(0.0283)$ & \\
\hline $\mathrm{E}$ & $-0.0176(0.0294)$ & \\
\hline W & $0.4007^{* * *}(0.0322)$ & \\
\hline CS & $0.3291^{* * *}(0.0329)$ & \\
\hline NE & $-0.3758^{* * *}(0.0337)$ & \\
\hline SE & $-0.0928^{* * *}(0.0292)$ & \\
\hline Woman & $-0.0733^{* * *}(0.0164)$ & $-0.0181^{* * *}(0.0020)$ \\
\hline Urban & $0.0751^{* * *}(0.0177)$ & $0.0042^{* *}(0.0021)$ \\
\hline Scholarship & $-0.0905^{* *}(0.0409)$ & $0.0012(0.0043)$ \\
\hline Remittances & $0.0913^{* * *}(0.0289)$ & $-0.0160^{* * *}(0.0033)$ \\
\hline Primary & $-0.0262(0.0294)$ & $-0.0070(0.0053)$ \\
\hline Secondary & $0.0004(0.0319)$ & $-0.0019(0.0054)$ \\
\hline High School & $0.0626^{*}(0.0359)$ & $0.0014(0.0057)$ \\
\hline Professional and graduate & $0.0444(0.0373)$ & $0.0068(0.0058)$ \\
\hline Unipersonal & $0.3940^{* * *}(0.0256)$ & $0.0179^{* * *}(0.0037)$ \\
\hline Extended & $0.1117^{* * *}(0.0191)$ & $0.0031(0.0023)$ \\
\hline Composite & $0.3033^{* * *}(0.0794)$ & $0.0070(0.0068)$ \\
\hline Co-resident & $0.1882^{*}(0.1136)$ & $0.0357^{* *}(0.0166)$ \\
\hline G4 & $-0.1395^{* *}(0.0588)$ & $-0.0239^{* * *}(0.0059)$ \\
\hline IMR & & $-0.0321^{* * *}(0.0046)$ \\
\hline Constant & $-3.4787^{* * *}(0.1397)$ & $0.7914^{* * *}(0.0270)$ \\
\hline Observations & 87,274 & 24,626 \\
\hline $\mathrm{R}^{2}$ & & 0.140 \\
\hline Log Likelihood & $-48,007.67$ & \\
\hline F Statistic & & $160.1489^{* * *}(\mathrm{df}=25 ; 24600)$ \\
\hline
\end{tabular}

${ }^{1}$ Standard errors in parentheses (for OLS, bootstrapped estimates after 2,000 samples); ${ }^{*} \mathrm{p}<0.1$; ${ }^{* *} \mathrm{p}<0.05 ;{ }^{* * *} \mathrm{p}<0.01$. Source: own elaboration with data from Instituto Nacional de Estadística $\mathrm{y}$ Geografía (INEGI) [1].

The coefficient associated to the Inverse Mills ratio (IMR) in the latter step is statistically significant, which indicates that the correlation between the error term from the participation equation and the error term from the level equation is different than zero. Therefore, the FAFH expenditure can be represented as a two-stage process.

The variables used in the first stage of the analysis are like those in the model for the probability of FAFH expenditure in Mexico proposed by Llamas Huitrón et al [25]. The 
Working-Lesser Engel curve was estimated on the same variables from the first step, plus the $I M R$, minus those dropped out by stepwise regression.

All variables in the second step present a VIF below the cut-off value of 10; thus, collinearity is not present in the model. On the other hand, since he standard errors from the OLS estimates are prone to heteroskedasticity, we present bootstrapped standard errors instead.

The coefficient for the log of income in the Working-Lesser Engel curve is both negative and statistically significant, as expected. The corrected conditional elasticity at the mean of the data is 0.4609 . The positive sign indicates that FAFH expenditure is regarded as a necessity good by the Mexican households that kept spending in 2020.

\section{Discussion}

The results of this research suggest that Mexican households in the sample devoted $29.17 \%$ of their income on total food, i.e., food-at-home (FAH) and food-away-from-home FAFH. FAH accounted for $26.40 \%$, whereas FAFH for $2.76 \%$ (of which actual monetary expenditure on goods and services for the household, or G1, accounting for $2.71 \%$ ). By comparison, Hispanic households in the United States (about half of them of Mexican origin) spent $29.4 \%$ of their income on total food; $25.8 \%$ on FAH, and $3.6 \%$ on FAFH [25].

In keeping with the findings of Llamas Huitrón et al [25], the results of the first stage in our analysis indicate that the presence of family members 65 years of age and older inhibit the participation in FAFH expenditure. Although this effect was already present in the 1992 and 2008 surveys, this age group was deemed the most prone to develop severe coronavirus disease 2019 (COVID-19) symptoms, therefore, this might be one of the factors behind the sharp fall in the participation observed in 2020. As in the study for the 2008 data, the coefficients for age, household size, and woman are negative and statistically significant, whereas the coefficient for urban and employed are positive and statistically significant; however, this study doesn't mention whether the sample design was taken into consideration. Furthermore, we found a negative and statistically significant coefficient for scholarship.

Besides taking into consideration the sample design in our model, one contribution of this study is the addition of dummy variables to indicate whether the household experienced food insecurity and whether it received remittances. Our proxy for food insecurity showed a negative and statistically significant coefficient, whereas we found a positive a statistically significant coefficient for remittances in the participation equation. Both variables reduce the budget share in the level equation.

The estimation of income elasticity is lower than the one for Argentina (0.824) [20] and Malaysia (0.9075) [23], under the same Engel curve specification. However, it is closer to the one for Hispanic households in the United States (0.4847) [22]. In the case of Slovakia, the elasticities are 0.740 (conditional) and 1.373 (unconditional) [16].

\section{Conclusion}

During the previous century, jobs displaced by the technology were absorbed by the service sector of the economy. This was even seen as a sign of a developed nation, a desirable feature. However, events triggered by the current pandemic exposed the vulnerability of this strategy.

There is uncertainty about whether the coronavirus disease 2019 (COVID-19) will become endemic, therefore we should bear in mind that seasonal peaks could bring about interventions aimed at reducing the spread of the infection. Compared with previous pandemics, the availability of data allowed us to track closely the impact of the current pandemic at the household level. Using data from Mexico, we observed a sharp drop in FAFH expenditure across all income deciles and regions. We further anticipate that, in these setting, as the population of the country ages, the likelihood of severe symptoms will dampen the participation outdoor activities, and expenditure in the service sector of the economy, which was supposed to absorb the younger population. 
Author Contributions: Conceptualization, data assembling and analysis, writing-original draft preparation, funding acquisition A.A.-L. writing-review, editing and supervision A.K. All authors have read and greed to the published version of the manuscript.

Funding: This research was funded by TECNOLÓGICO NACIONAL DE MÉXICO, grant number 10415.21-PD.

Data Availability Statement: The data used in this project may be found at: https://www.inegi.org.mx/programas/enigh/nc/2020/

Acknowledgments: The authors are grateful for the helpful comments and suggestions made by Dan Silva-López Ph.D. and José Edigardo Hernández-Martínez, MSc.

Conflicts of Interest: The authors declare no conflict of interest.

\section{References}

1. Encuesta Nacional de Ingresos y Gastos de los Hogares (ENIGH) 2020 nueva serie. Available online: https://www.inegi.org.mx/programas/enigh/nc/2020/ (Accessed on 2 August 2021).

2. El Economista. Available online: https://www.eleconomista.com.mx/capitalhumano/Pandemia-redujo-en-10-en-promedio-elnivel-de-los-salarios-en-Mexico-20210805-0122.html (accessed on 7 November 2021).

3. El Financiero. Available online: https://www.elfinanciero.com.mx/economia/mas-de-un-millon-de-establecimientos-cerrarona-causa-del-covid-19-en-2020-inegi/ (accessed on 7 November 2021).

4. El Economista. Available online: https://www.eleconomista.com.mx/economia/Mexico-recibio-40606-millones-de-dolares-enremesas-en-el-ano-de-la-pandemia-20210202-0052.html (accessed on 7 November 2021).

5. Chai, A.; Moneta, A. Engel Curves. Journal of Economic Perspectives 2010, 24, 225-240. https://doi.org/10.1257/jep.24.1.225

6. Byrne, P. J.; Capps, O. J. Does Engel's Law Extend to Food Away from Home? Journal of Food Distribution Research 1996, 27, 2232.

7. Stewart, H.; Blisard, N.; Bhuyan, S.; Nayga, R. M. The Demand for Food Away From Home. Full-Service or Fast Food? Agricultural Economic Report No. 829, 2004.

8. Prochaska, F. J.; Schrimper, R. A. Opportunity Cost of Time and Other Socioeconomic Effects on Away-From-Home Food Consumption. American Journal of Agricultural Economics 1973, 55, 595-603. https://doi.org/10.2307/1238344

9. Sexauer, B. The Effect of Demographic Shifts and Changes in the Income Distribution on Food-Away-from-Home Expenditure. American Journal of Agricultural Economics 1979, 61, 1046-1057. https://doi.org/10.2307/3180373

10. Kinsey, J. Working Wives and the Marginal Propensity to Consume Food Away from Home. American Journal of Agricultural Economics 1983, 65, 10-19. https://doi.org/10.2307/1240332

11. Lee, J.-Y.; Brown, M. G. Food Expenditures at Home and Away from Home in the United States--A Switching Regression Analysis. The Review of Economics and Statistics 1986, 68, 142-147. https://doi.org/10.2307/1924937

12. Yen, S. T. Working Wives and Food away from Home: The Box-Cox Double Hurdle Model. American Journal of Agricultural Economics 1993, 75, 884-895. https://doi.org/10.2307/1243976

13. Byrne, P. J.; Capps, O.; Saha, A. Analysis of Food-Away-from-Home Expenditure Patterns for U. S. Households, 1982-89. American Journal of Agricultural Economics 1996, 78, 614-627.

14. Mottaleb, K. A.; Rahut, D. B.; Mishra, A. K. Consumption of food away from home in Bangladesh: Do rich households spend more? Appetite 2017, 119, 54-63. https://doi.org/10.1016/j.appet.2017.03.030

15. Liu, H.; Wahl, T. I.; Seale, J. L.; Bai, J. Household composition, income, and food-away-from-home expenditure in urban China. Food Policy 2015, 51, 97-103. https://doi.org/10.1016/j.foodpol.2014.12.011

16. Cupák, A.; Pokrivčák, J.; Rizov, M. Demand for Food Away from Home in Slovakia. Czech Journal of Economics and Finance 2016, $66,354-369$.

17. Angulo, A. M.; Gil, J. M.; Mur, J. Spanish Demand for Food Away from Home: Analysis of Panel Data. Journal of Agricultural Economics 2007, 58, 289-307. https://doi.org/10.1111/j.1477-9552.2007.00106.x

18. Terin, M. Determining factors in food away from home expenditure of Turkish households. Applied Ecology and Environmental Research 2019, 17, 3441-3455. https://doi.org/10.15666/aeer/1702_34413455

19. McCracken, V. A.; Brandt, J. A. Household Consumption of Food-Away- From-Home: Total Expenditure and by Type of Food Facility. American Journal of Agricultural Economics 1987, 69, 274-284. https://doi.org/10.2307/1242277

20. García Arancibia, R. Curvas de Engel de alimentos fuera del hogar según circunstancia de consumo. El caso de Argentina. Cuadernos de Economía 2013, 32, 209-232.

21. Holcomb, R. B.; Park, J. L.; Capps, O. J. Revisiting Engel's Law: Examining Expenditure Patterns for Food at Home and Away From Home. Journal of Food Distribution Research 1995, 26, 1-8.

22. Lanfranco, B. A.; Ames, G. C. W.; Huang, C. L. Food expenditure patterns of the Hispanic population in the United States. Agribusiness 2002, 18, 197-211. https://doi.org/10.1002/agr.10011

23. Tey, Y.-S., Shamsudin, M. N., Mohamed, Z., Abdullah, A. M., \& Radam, A. Evidence of Engel curves in food away from home: A study of Malaysia. MPRA Paper 14833, 2009. 
24. Queiroz, P.; Coelho, A. B. Food away from home in Brazil: the role of sociodemographic factors and family structure. International Journal of Social Economics 2018. https://doi.org/10.1108/IJSE-03-2018-0113

25. Llamas Huitrón, I.; Charles Leija, H. A.; Aboites Manrique, G. Gasto en alimentos y bebidas fuera del hogar. El caso de México, 1992 y 2008. Economía: Teoría y Práctica 2012, 37, 177-198.

26. Garza-Montoya, B. G.; Ramos-Tovar, M. E. Cambios en los patrones de gasto en alimentos y bebidas de hogares mexicanos (1984-2014). Salud Pública de México 2017, 59, 612-620. https://doi.org/10.21149/8220

27. Saha, A.; Capps, O.; Byrne, P. J. Calculating marginal effects in models for zero expenditures in household budgets using a Heckman-type correction. Applied Economics 1997, 29, 1311-1316. https://doi.org/10.1080/00036849700000021 